599b2-3); and 'most of them [sc. fish] hide in winter' ( $\tau \dot{\alpha} \mu \dot{\varepsilon} \nu$ oûv $\pi \lambda \varepsilon \hat{\imath} \sigma \tau \alpha \varphi \omega \omega \varepsilon \hat{\imath}$ $\tau o \hat{v} \chi \varepsilon \mu \omega \hat{\omega} v o s, 599 \mathrm{~b} 27-8)$. Note too that this is an ancient variant of the title of the Historia animalium not mentioned by Schnieder in his discussion of titles attributed



My aim in this note was not to level a criticism against Schnieder for a serious omission but to supplement and support his excellent discussion by adding these two obscure texts to the evidence he presents.

Seton Hall University

ROBERT MAYHEW

robert.mayhew@shu.edu

doi:10.1017/S0009838821000549

\title{
THREE GREEK PROPER NAMES IN OVID, METAMORPHOSES BOOK $10 *$
}

\begin{abstract}
This paper discusses the transcription of three Greek proper names in Ovid, Metamorphoses Book 10. It argues that we should read Haemon (10.77), Amycliade (10.162) and Panchaica (10.309) rather than Haemum, Amyclide and Panchaia.
\end{abstract}

Keywords: Ovid; Metamorphoses; textual criticism; Graeca Latine; missing letters

Proper names, especially Greek ones, are more subject to corruption in Latin manuscripts than other words. The restoration of the correct forms is not always easy. When metre provides no guidance, it is often unclear to what extent they retained Greek morphology or were adapted to Latin inflection. It can also occur that a place or a character is only known from a single Latin source. Likewise, derivative adjectives or patronymics used by Latin poets might not be documented in extant Greek texts. Since all these problems are recurrent in Ovid, it is often possible to call into question the transcription of Greek words.

I shall try to exemplify this with the help of three passages of Ovid's Metamorphoses Book 10. I take Tarrant's OCT text ${ }^{1}$ as a starting point, but I add my own critical apparatus, in which I provide more readings from the recentiores. ${ }^{2}$

* I wish to thank Drs Juan Antonio Estévez, Dániel Kiss, Bartomeu Obrador, Antonio Ramírez de Verger and Luis Rivero for their useful suggestions. I am also very grateful to $C Q$ 's anonymous referee and to Professor Bruce Gibson for their valuable advice. This paper is based on my doctoral dissertation, which I am now revising for publication: P. Fàbregas Salis, 'Edición crítica y comentario textual del libro X de las Metamorfosis de Ovidio' (Diss., University of Barcelona, 2016).

${ }^{1}$ R.J. Tarrant (ed.), P. Ovidi Nasonis Metamorphoses (Oxford, 2004).

${ }^{2}$ I use the sigla available at http://www.uhu.es/proyectovidio/esp/index.html. I omit most variants that are merely orthographical. 
(1) $10.76-7$

[Orpheus] in altam $\mid$ se recipit Rhodopen pulsumque aquilonibus ${ }^{3}$ Haemum

77 (h)(a)emum $\Omega$, edd. plerique: (h)(a)emon B3DrEsV6 A7Ld7(ut uid.) Es2 Bs $7 \mathrm{Lr} 26 \mathrm{Nr} 3^{3 s} \mathrm{V44}$, Heinsius, rectius

Almost all manuscripts read $(H)($ a)emum, but a group of recentiores from the twelfth century onwards has $(H)(a)$ emon. Heinsius printed it with the following comment: 'Haemon pro Haemum tres scripti [for example Ld7 Bs7Lr26 Nr3 ${ }^{3 \mathrm{~s}}$ ]. sic \& alibi non semel' ${ }^{4}$ Cf. Met. 2.219, ${ }^{5}$ 6.87, ${ }^{6}$ Pont. 4.5.5. ${ }^{7}$ However, Heinsius ${ }^{8}$ kept Haemum at Her. 2.113. Tarrant says nothing about this in his appendix. ${ }^{9}$ Unfortunately, in all the examples cited the word appears at the end of the line, so metre does not reveal whether Ovid used one form or the other. ${ }^{10}$ None the less, there is no denial that he was especially fond of Greek forms. ${ }^{11}$

To give a couple of examples, Virgil undoubtedly wrote Cyprum, Polyphemum and Menelaum, as the subsequent elisions show:

Aen. 1.622 uastabat Cyprum et uictor dicione tenebat Aen. 3.657 pastorem Polyphemum et litora nota petentem Aen. 6.525 intra tecta uocat Menelaum et limina pandit

But Ovid opted for the Greek endings without elision: ${ }^{12}$

Met. 10.718 Cypron olorinis nondum peruenerat alis

Met. 13.772 terribilem Polyphemon adit 'lumen'que, 'quod unum

Met. 14.167 fatur Achaemenides: 'iterum Polyphemon et illos

Her. 5.105 ardet amore tui? sic et Menelaon amauit

Her. 17.249 tu fore tam iusta lentum Menelaon in ira

Let me list further examples of accusatives in -on guaranteed by the metre in the Metamorphoses: 2.83 Scorpion (cf. Fast. 5.541); 2.415 Maenalon (2.442); 3.539 Tyron; 3.636 Naxon; 4.283 Crocon (cf. Fast. 5.227); 4.466 Sisyphon (13.26); 4.786

${ }^{3}$ Perhaps we should capitalize this word here and in some other places, as Heinsius did: N. Heinsius (ed.), P. Ovidii Nasonis operum tomus II (Amsterdam, 1659), 219. Cf. e.g. Ov. Met. $1.262,7.3,13.726$.

${ }^{4}$ Heinsius (n. 3), 260n.

${ }^{5}$ Heinsius (n. 3), 33n.: 'Haemos Barberinus [V10], ut alibi'.

${ }^{6}$ Heinsius (n. 3), 133n.: 'Haemon decem veteres'.

${ }^{7}$ N. Heinsius (ed.), P. Ovidii Nasonis operum tomus III (Amsterdam, 1661), 406n.: 'Haemon Fragmentum Vatic. et Gryphii editio. sic \& et in Metamorph.'.

${ }^{8}$ N. Heinsius (ed.), P. Ovidii Nasonis operum tomus I (Amsterdam, 1658), 11.

${ }^{9}$ Tarrant (n. 1), 488.

${ }^{10}$ We do have, in another position, the vocative Haeme (Fast. 1.390), but this is not helpful either. Nor could I find any examples of Haemum or Haemon confirmed by the metre in any other Latin poet (again, the word usually appears at the end of the line).

${ }^{11}$ See, for instance, M. Pulbrook, 'Ovid, Metamorphoses Book IV' (Diss., University of London, 1973), 236-42, who has shown, according to the evidence available to him, that Ovid had much more frequent recourse to nominatives in -os than Virgil.

${ }^{12}$ Likewise, Virgil always used the neuter Ilium (e.g. Aen. 1.68 Ilium in; 6.64 Ilium et), whereas Ovid wrote Ilion (Her. 7.151 Ilion in; 13.53 Ilion et; 16.49 Ilion igni; 16.181 Ilion aspicies; 17.240 Ilion arsurum; Rem. am. 163 Ilion armis; Met. 6.95 Ilion illi; 13.408 Ilion ardebat; 13.505 Ilion ingens; 14.467 Ilion et-it is irrelevant whether some of these examples could actually belong to the feminine Ilios). 
Pegason; 7.365 Rhodon; 7.413 Cerberon; 7.466 Siphnon; 7.500 Clyton; 8.261 Daedalon; 8.270 Meleagron; 8.798 Caucason; 9.435 Aeacon (9.440, 13.27); 9.440 Rhadamanthon; ${ }^{13}$ 9.646 Cragon; 10.217 Hyacinthon; 10.530 Paphon (cf. Am. 2.17.4; cf. also Ars am. 2.588, Met. 10.297); 11.762 Aesacon (12.1); 12.215 Hymenaeon (cf. Pont. 1.2.131); 12.262 Orion; 12.352 Hippason; 12.378 Phlegraeon; 12.408 Cyllaron; 12.433 Tectaphon (dubium); 13.171 Telephon; 13.257 Coeranon; 13.260 Ennomon; 13.726 Lilybaeon; 14.223-4 Aeolon; 15.61 Samon.

It is noteworthy that none of these forms coexists with a metrically guaranteed form in -um in Ovid's corpus. It is also important to note that at 9.440 the metre demands Rhadamanthon, but that did not prevent the scribe of $\mathrm{M}$ from writing $R(h)$ adaman$t(h) u m$. Likewise, at 13.27 and 13.772 some manuscripts, including some antiquiores, wrongly give the form in $-u m .{ }^{14}$ This strongly suggests that Greek endings are likely to be substituted for Latin ones, as Housman proved for accusatives in -an or $-e n .{ }^{15}$ From this, I infer that, whenever there is some evidence for the Greek form in Ovid, we should adopt it.

(2) 10.162

'te quoque, Amyclide, posuisset in aethere Phoebus

162 amyclide $\Omega$, edd.: am(y/i)cliade $\operatorname{Dr} E s 5$, e coni. Unger: amycliades $G f 6^{a c}$ : amyclaide etiam Unger, Merkel, prob. Luck: amiclides Cs BoLr14: amiclede $A^{a c}$ : amiclate $\operatorname{Lr} 7$ : amiclade So Bo2To2

The patronymic Amyclides is attested only here. It alludes to Hyacinthus, whom elsewhere Ovid calls Taenarides (Met. 10.183), Oebalides (10.196, Ib. 588) or Oebalius (Met. 13.396). According to Bömer, ${ }^{16}$ Amyclides is probably the true patronymic for Hyacinthus. ${ }^{17}$ At the very least, the use of Amyclides shows that Ovid was aware of a tradition in which Amyclas was Hyacinthus' father (Simmias, fr. 8 Powell; Paus. 3.1.3; Apollod. Bibl. 3.116; Schol. Nic. Ther. 902-3a; Tzetz. Chil. 244-5).

The scansion Amyclìdes would be formed upon an irregular 'A $\mu \nu \kappa \lambda \varepsilon i \delta \eta \varsigma$ created


Met. 1.390 Promethides). This is not impossible: cf. Verg. Aen. 2.82 Belïdae (Cinna, fr. 1.3 Blänsdorf; Ov. Her. 14.73); 7.484 Tyrrhīdae ${ }^{18}$ Ov. Met. 12.433 Olenīden; 15.624 Coronīden; Prisc. Inst. 2.67.9-13 Hertz. ${ }^{19}$ However, Unger ${ }^{20}$ conjectured Amycliade

${ }^{13}$ Cf. Tarrant (n. 1), 493: 'r(h)adamant(h)on SNU FLP : -um $M$ : -en $B^{c}$ (ut uid.)'.

14 See L. Rivero García, Book XIII of Ovid's Metamorphoses: A Textual Commentary (Berlin and Boston, 2018), 419 and 509.

15 A.E. Housman, 'Greek nouns in Latin poetry. From Lucretius to Juvenal', JPh 31 (1910), 23666 (= Classical Papers [Cambridge, 1972], 2.817-39). I am aware that in some special cases the Greek inflection could be imposed upon Latin words (e.g. Achillen or Vlixen), but this does not invalidate the whole point.

${ }^{16}$ F. Bömer, P. Ovidius Naso, Metamorphosen: Kommentar: Buch X-XI (Heidelberg, 1980), 73.

17 Although Bömer admits it could simply mean 'Spartan'. Cf. e.g. Verg. G. 3.89, 3.345.

18 See N. Horsfall, Virgil, Aeneid 7. A Commentary (Leiden, 2000), 326.

19 See e.g. V. Loers, P. Ovidii Nasonis Heroides et A. Sabini Epistolae (Cologne, 1829), 334-5 (on Her. 14.73); R. Unger, Analecta Propertiana scripsit; quaestiones Philetaeas atque emendationes Arnobianas interposuit (Halle, 1850), 7; C.T. Angermann, De patronymicorum Graecorum formatione (Leipzig, 1868), 15-16, 31 n. 1 and 32-4; A.E. Housman, 'Palmer's Heroides of Ovid', CR 13 (1899), 172-8, at 177 (on 14.73) (= Classical Papers [Cambridge, 1972], 2.479).

${ }^{20}$ Unger (n. 19), 7. 


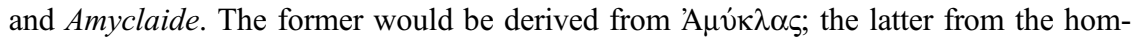

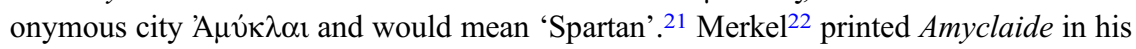
second edition, but he was not followed by subsequent editors. Only Luck ${ }^{23}$ favoured Amyclaide, pointing out the similarity with 4.1 Minyeias ('M man. 2, Scaliger, Heinsius: minyas vel mineias vel similia $\Omega$ '); ${ }^{24} 14.87$ Acheloiadumque ('U ex corr. $\mathrm{W}$, Constant. Fanensis et Naugerius ex coni.: Acheloidumque $\Omega$ '); ${ }^{25} 15.386$ Cythereiadasque ('b man. 2 k man. 2, Constant. Fanensis et Naugerius ex coni.'). ${ }^{26}$ We could add, among other examples, Met. 6.414 Pelopeiadesque Mycenae; Fast. 2.43 Amphiareiades; ${ }^{27}$ Ib. 295 Amyntiaden; Ib. 345 Dryantiadae;28 Ib. 503 Lycurgiaden; ${ }^{29}$ Ib. 631 Cliniadaeue. ${ }^{30}$ The examples just quoted rather stand for Amycliade, which is actually the reading of Dr Es5, while Gf6 $^{\text {ac }}$ reads Amycliades. ${ }^{31}$ Furthermore, these examples show that omission of letters, often that of $-a-$, is usual

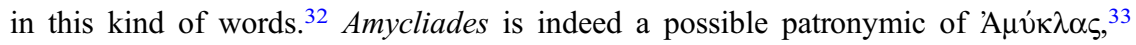
just like we have Amyntiades from Amyntas (Ib. 295), Anchisiades from Anchises (Verg. Aen. 5.407 and elsewhere) or Thyestiades from Thyestes (Ov. Ars am. 2.407). Furthermore, Ovid's liking for alluding to mythographical variants is well known. To my mind, an allusion to a tradition that made Hyacinthus the son of Amyclas makes much more sense than a dull reference to a city or a geographic area. ${ }^{34}$ I think we ought to read Amycliade.

(3) 10.309

tura ferat floresque alios Panchaia tellus

309 panc(h)aia GfHLr2M, recc., edd. plerique: panc(h)aica AL3LrLuNTV3, recc., edd. ueteres aliquot, prob. Luck: alii aliter


[n. 19], 11 and 26-7).

${ }^{22}$ R. Merkel (ed.), P. Ovidius Naso ex iterata R. Merkelii recognitione. Vol. II Metamorphoses cum emendationis summario (Leipzig, $1875^{2}$ ), 200.

${ }^{23}$ G. Luck, 'More missing letters in Ovid's Metamorphoses', MH 66 (2009), 88-119, at 107.

${ }^{24}$ Luck (n. 23), 107; cf. Tarrant (n. 1), 490.

${ }^{25}$ Luck (n. 23), 107; cf. Tarrant (n. 1), 483.

${ }^{26}$ Luck (n. 23), 107; cf. Tarrant (n. 1), 486; G. Luck, A Textual Commentary on Ovid, Metamorphoses, Book XV (Huelva, 2017), 73.

${ }^{27}$ E.H. Alton, D.E.W. Wormell and E. Courtney (edd.), P. Ovidi Nasonis Fastorum libri sex (Stuttgart and Leipzig, 1997 ${ }^{4}$ ), 26: 'nomina varie corrupta, velut amphiaraides (sic 5 ...)'.

${ }_{28}$ A. La Penna (ed.), Publi Ovidi Nasonis Ibis (Florence, 1957), 85: 'driantiade $\mathbf{G}^{\mathbf{2}}$ dryantide $\mathbf{o P}_{\mathbf{2}}$ driantides P driant(th)ide cett. Conr.'.

${ }^{29}$ La Penna (n. 28), 130: 'ligurgidē GPP $\mathbf{T}$ TFVHAZ ligurgidem xy Conr. ligurgeiden $\mathbf{V}_{\mathbf{1}}$ ligurgitē o (c supra prior. g) lygurgiaden $\mathbf{P}_{\mathbf{2}}$ ligurgiadē $\mathbf{E}$ ligugides Schol. Bern. licorciden in ligorciden corr. cod. Bobiensis Eutychis'.

${ }^{30}$ La Penna (n. 28), 170: 'Cliniadeve ex manu rec. in $\mathbf{x}$ Cliniadeque $\mathbf{P}_{\mathbf{1}}$ Clitiadeve $\mathbf{m}_{\mathbf{2}}^{2}$ Clitiadeque $\mathbf{l}_{2} \mathbf{m}_{31}^{2}$.

${ }_{31}$ Other variant readings might also point in that direction: Amiclate $(\operatorname{Lr} 7)$ and Amiclade (So Bo2To2).

${ }^{32}$ Therefore, it seems unlikely that scribes could actually recognize Amyclide as metrically defective. In consequence, the readings of $\mathrm{Dr} \mathrm{Gf6}{ }^{\mathrm{ac}} \mathrm{Es} 5$ can hardly be attempts at prosodic correction. On a general basis, single letters were often omitted in this paradosis, especially in Greek words: cf. Luck (n. 23), 103.

33 Angermann (n. 19), 25-8.

${ }^{34}$ In spite of Claud. Raptu Pros. 2.133 tu natus Amyclis [sc. Hyacinthus]. 
The manuscripts are split, offering Panchaia and Panchaica. ${ }^{35}$ Heinsius commented: 'Panchaïa meliores [for example HM EHdLr3P2 P24 Bo3 ${ }^{\mathrm{ac}}$ ]. bene'. ${ }^{36} \mathrm{He}$ compared it to Verg. G. 2.139 (totaque turiferis Panchaïa pinguis harenis), but there Panchaia is a noun (as in Lygd. 2.23; Val. Fl. 6.119; Claud. III Cons. Hon. 211, Raptu Pros. 2.81; Plin. HN 7.197, 10.4). He also mentioned App. Verg. Culex 87 Panchaia tura, where Panchaia is an adjective, but the reading is not quite certain, because the best manuscripts offer Pancheia ( $\Gamma$ ) or Panchasia (V), while Panchaia is attested in $\mathrm{CL}, 37$ 'the least estimable MSS of the poem'. ${ }^{38}$ The only well-attested example of Panchaius seems to be Mela 3.81, who calls the inhabitants of the island Panchai. On the other hand, I have found only one example of Panchaicus: Arn. Adu. nat. 7.27.

Since the evidence for Panchaius/Panchaicus is clearly poor, I suggest that we examine a parallel and well-documented doublet: Achaius/Achaicus. The alternation occurs at Verg. Aen. 2.462, where MP $\omega \gamma$ read Achaica castra and Fcy read Achaia castra. ${ }^{39}$ The variation could be explained by the scribal distaste for the cacophonic syllabic combination $-c a c a-{ }^{40}$ None the less, the same variation also occurs in other contexts where there is no cacemphaton. ${ }^{41}$ In general, adjectives in -icus often loose the letter $-c$ - in manuscripts. For instance, in Ov. Met. 2.727 some manuscripts read Balearia instead of Balearica. ${ }^{42}$ In Ov. Met. 3.518 the adjective Bacchica (B $\alpha \kappa \chi 1 \kappa o ́ \varsigma$,

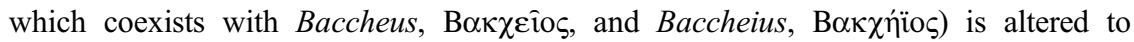
Bacchia in some manuscripts. ${ }^{43}$

On the other hand, the adjective Achaeus, which is the right transcription of 'A $\chi \alpha$ ió $\zeta$,

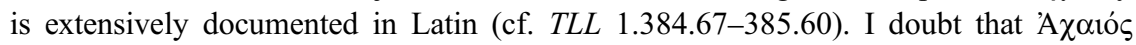
could be transcribed both as Achaeus and Achaïus, with a different scansion. Furthermore, apart from Achaïus (and Panchaïus), I can find no other example of any Greek adjective in $-\alpha \operatorname{los}$ (or in $-\alpha 1 F o \varsigma$ ) ${ }^{44}$ being transcribed into Latin as -aïus. Therefore, I believe that Diehl (TLL 1.284.8-11) is right when he points out that Achaius is only a scribal misspelling of Achaicus. ${ }^{45}$ The analogy with adjectives in -ius and the noun Achaia, in combination with the scholastic doctrine against cacemphaton, probably smoothed the way for Achaius to substitute Achaicus.

${ }^{35}$ As an alternative, Latin language had the adjective Panchaeus, which is the right transcription of $\Pi \alpha \gamma \chi \alpha \hat{i o s}$. This is used by Ovid at Met. 10.478. Panchaeaque is rightly edited at Claud. Carm. mai. 10.94 instead of Panchaiaque.

${ }^{36}$ Heinsius (n. 3), 267n.

37 W.V. Clausen et al. (edd.), Appendix Vergiliana (Oxford, 1966), 22.

38 W.V. Clausen, 'The textual tradition of the Culex', HSPh 68 (1964), 119-38, at 124. Could the obvious errors in $\Gamma$ and V suggest that the archetype was subject to some corruption?

39 G.B. Conte (ed.), P. Vergilius Maro. Aeneis (Berlin and Boston, $2019^{2}$ ), 45.

40 At Aen. 2.27 and 6.88 Servius wanted to read Doria castra instead of Dorica castra to avoid the cacemphaton. See also P. Burman (ed.), P. Virgilii Maronis opera (Amsterdam, 1746), 2.273-4 (on 2.462); but cf. N. Horsfall, Virgil, Aeneid 2. A Commentary (Leiden, 2008), 356-7 (on 2.462).

${ }^{41}$ e.g. Verg. Aen. 5.623; Ov. Met. 12.70; App. Verg. Catal. 5.2; Manil. 4.614; Sil. Pun. 14.5, 15.306; Ilias Latina 790. Cf. TLL 1.384.15 'Achaius, quod haud raro eodem loco atque Achaicus traditur'.

42 W.S. Anderson (ed.), P. Ovidii Nasonis Metamorphoses (Munich and Leipzig, $1982^{2}$ ), 49.

${ }^{43}$ Heinsius (n. 3), 69n. See also A. Suárez del Río, 'Edición crítica y cometario textual del libro III de las Metamorfosis de Ovidio’ (Diss., University of Huelva, 2015), 363-4.

${ }^{44}$ P. Chantraine, La formation des mots en grec ancien (Paris, 1933), 46; E. Risch, Wortbildung der homerischen Sprache (Berlin and New York, 1974²), 126-7.

${ }^{45}$ See also Enciclopedia Virgiliana (Rome, 1984), 1.21-2. 
Let me address one final question about the adjectives from Achaia. As often, Ovid also used derivatives in -is (Met. 3.511, 5.306, 15.293; 5.577, 7.504 [nouns]) and in -ias (Her. 3.71). In the Metamorphoses, Tarrant ${ }^{46}$ accepted the transmitted form Achais, even if Ovid clearly kept the Homeric form Achaeias at Her. 3.71 (Achaeiadas ... matres) ${ }^{47}$ Kenney ${ }^{48}$ suggested that it was very likely that Ovid had also retained the transcription Achaeis in the Metamorphoses (it appears in some old editions). Indeed, Achaeis and Achaeias are the expected transcriptions of 'A $\chi \alpha$ iis (for example Hom. Il. 1.254) and 'A $\chi \alpha i$ itas (for example Hom. Il. 5.422). ${ }^{49}$

As for Achaicus, Kenney recalled that since Homer the regular Greek form was 'A $\chi \alpha$ ïкós (for example Il. 9.141), and we could expect that Latin poets transcribed Achaeicus rather than Achaicus. But Keeney also knew that this was a complicated issue, since Achaicus relies on the authority of the ancient Virgilian manuscripts (see above; this form is also attested in Hor. Carm. 1.15.35; cf. TLL 1.384.14-42). Perhaps we should consider the possibility that the Latin adaptation had been filtered

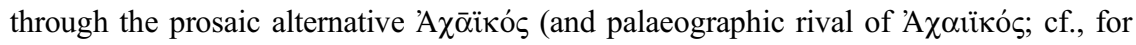
example, Eur. Hec. 521).

All these observations apply, I think, to Panchaius and Panchaicus. If we accept the illegitimacy of Achaius, we must conclude that Panchaius is simply a form attested in


Thus Panchaeus and Panchaicus would stem from Panchaia, just like Achaeus and Achaicus stem from Achaia. ${ }^{50}$ Other parallels are available: Phocaea produces

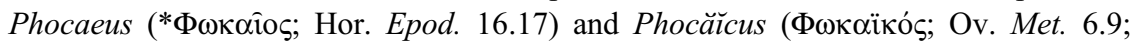

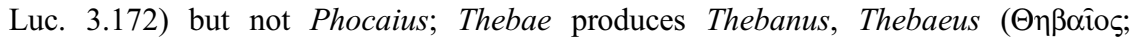

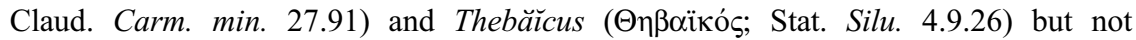
Thebaius. ${ }^{51}$ For all these reasons, I think we should restore Panchaica. ${ }^{52}$ This had been printed by some editors up to Heinsius and was recently favoured by Luck ('read probably'). ${ }^{53}$

Universitat de Barcelona

PERE FÀBREGAS SALIS pfabregasuni@gmail.com doi:10.1017/S0009838821000380

${ }^{46}$ Cf. Tarrant (n. 1), 483.

${ }^{47}$ Cf. H. Dörrie (ed.), Publi Ovidi Epistulae Heroidum (Berlin, 1971), 67. See also A. Barchiesi, $P$. Ovidii Nasonis Epistulae Heroidum 1-3 (Florence, 1992), 224.

${ }^{48}$ E.J. Kenney, 'Textual notes on Ovid, Metamorphoses 7-9', CQ 51 (2001), 545-50, at 546.

49 Luck (n. 23), 103 also wanted to restore these forms in Ovid.

50 As stated earlier, -aeus (not -ä̈us) is the legitimate transcription of adjectives in - $\alpha$ los.


Chantraine (n. 44), 385-6; id., Dictionnaire étymologique de la langue grecque: histoire des mots

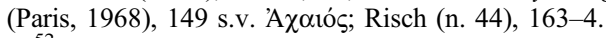

52 This might even be the right reading for App. Verg. Cul. 87, while for Mela 3.81 I would suggest Panchaei. On the contrary, I do not think we should write Panchaeica.

${ }^{53}$ Luck (n. 23), 107. 